Journal of Urban and Regional Analysis, vol. XII, 1, 2020, p. 75 - 90

https://doi.org/10.37043/JURA.2020.12.1.5

\title{
MIGRATION AND INVESTMENT ACTIVITY IN THE REGIONS OF THE SIBERIAN FEDERAL DISTRICT OF THE RUSSIAN FEDERATION
}

\author{
Kseniya PARFENOVA, Olga GUROVA \\ Siberian Branch of the Russian Academy of Sciences, Chita, Russia
}

\begin{abstract}
This article analyses the migration and investment activity processes in constituent entities of the Russian Federation located in the Siberian Federal District (SFD). The research was performed on the basis of official statistical data with geographical visual reference. The study was performed in the mono-specialized cities of SFD regions on the basis of official statistics within the context of the creation of Priority Social and Economic Development Areas (PSEDA). A negative migration balance is registered in SFD regions and mono-specialized settlements. Investment activity in SFD territories, their regional potentials and risks were analyzed. Krasnoyarsk Territory, Tomsk Region, Irkutsk Region, Novosibirsk Region, and Kemerovo Region stand out among the SFD regions by their investment activity level and social and economic development. At the current stage of social and economic development, Priority Social and Economic Development Areas can be successfully created in the regions which are the most developed both industrially and innovatively and in the mono-specialized settlements with the most favorable start conditions.
\end{abstract}

Key Words: migration of population, mono-specialized cities, investments, investment risk, investment potential, Priority Social and Economic Development Areas, Siberian Federal District.

\section{Introduction}

Currently, the migration issue is one of the urgent problems in Russia. The attitude of the population towards migration actually reflects the level of its social and economic development, the quality of life in the region and the perspectives for development. Migration mobility reflects the peculiarities of the population retention in the region and the acclimation of the migrants, and thus it characterizes the functioning of the economic space and the influence of internal and external factors on the latter.

The relevance of the research on migration issues in the country is determined by the problems of transregional differences in the social and economic development of the territories, while migration factors of attraction and repulsion play the crucial role. A gradual decrease of population, decreased birth rates against the background of relatively high mortality and depopulation are observed in the remote and border regions of strategic importance in the context of geopolitical interests of the country. Problems arising at regional labor markets are intensified by the growing selective migration, and the declining working-age population and skilled personnel. Consequently, the necessity to ease this tension is an acute problem in specialized monosettlements which depend mostly on singular production, have less opportunities for the diversification of the economy and, correspondingly, are less viable under market conditions. Mono-specialization of economic development in the majority of settlements in the regions of the country has been maintained since the Soviet period; the transition towards market conditions has only worsened the spiraling social and economic crisis. The current degradation of the urban environment in depressed cities is accompanied by a considerable migratory mobility of their population, making the situation only worse. 
Taking into account the growing migration of population from the eastern regions of the country to its western part, we should mention that the problem of formation and preservation of demographic and labor resources keeps getting worse not only in large cities, but particularly in mono-specialized settlements. Mostly this tendency is observed in the territories of Siberia and the Far East suffering from all the results of the "migration pump".

The current situation with the demographics and the migration movement of the population in Russia requires the development of new government solutions on the socio-economic development of the country's regions aimed at improving the living conditions of the residents. In order to improve the quality of life of the population in the regions and, accordingly, to reduce the migration outflow of the residents, the creation of territories of priority social and economic development is being proposed. To a greater extent, these measures are aimed at improving the socio-economic development of single-industry towns, diversifying their economies, and reducing the stress on the regional labor markets. The Federal Law No. 473- $\$ 3$ On Creating Territories of Advancement of Socio-Economic Development (hereinafter referred to as PSEDA) was passed in 2014. It provides for the creation of territories within one or more municipal entities for 70 years with the right to extend, with a special legal regime for the implementation of-entrepreneurial and other activities in order to create an enabling environment for attracting investments while ensuring accelerated economic development and creating comfortable conditions for the livelihood of the population. Investing in PSEDA projects is supposed to be based on public-private partnerships. So, on the part of the state, the PSEDA resident companies are provided with preferences in the form of benefits for the payment of income and property, a reduction of more than 3 times the volume of insurance fees, as well as co-financing from the Monotown Development Fund. An urgent task is to attract anchor investors (i.e. large companies) including the foreign ones. According to the requirements for investment projects, the minimum amount of capital investments of a PSEDA resident into a project in the first year is of 5 million rubles, with the minimum number of permanent jobs created in the first year of the project being that of 20 jobs. Initially, such territories have been created in the Far East, then in Siberia and other regions. They are aimed at assisting in the economic development of mono-specialized cities and the improvement of the quality of life.

Given that one of the main features of this law is the investment component, the developers of this document rely not only on improving the life of the population of the single-industry towns, but also on preserving their labor resources, as well as on the movement of human capital after investments. And to a large extent this applies to the foreign migrants. In addition, the implementation of the law can contribute to the development of support for domestic investment, which will change the geography of migration flows within the regions - labor resources will be in demand at the place of residence, without the fly-out work trips and pendulum migration.

The well-known expression "migrants follow investments" (Javorcik et al. 2011, Fensore 2017, Kugler et al. 2017, Burchardi et al. 2019) gives hope for the stabilization of the migration flows of compatriots both at the national level and in individual settlements. Therefore, the authors of the article deem it important to, first of all, characterize the situation with the migration movement of the Russian population and the investment activity in the regions under consideration. The investment opportunities that the state offers in the form of this law can help to solve the problem of migratory loss of the population locally, at the micro level, by directing targeted assistance to rehabilitate the situation in single-industry towns. Modern migration is not only the result of not only the existing socio-economic development of the country and its regions, but it is also a deeper phenomenon of the transformation of the lifestyle of Russians, and changes in the entire rural-urban continuum. Therefore, it is necessary to perform regional research aimed at the analysis of the current mechanisms for the improvement of the social and economic quality of life of the population in the Siberian regions. 
The existence of development problems of the specialized monosettlements, their restructuring and migrational non-wellbeing is a well-known problem in the world (Everitt and Gill 1993, Halseth and Sullivan 2003, Anas and Xiong 2005, Bartik 2009, Agrawal et al. 2010, Bański et al. 2016, Berube and Murray 2018). A unique specificity for each country is the choice of its own mechanisms and incentives to solve the existing problems. Recently, more and more works have been devoted to the issue of the functioning and socio-economic development of single-industry towns in the Russian Federation (Animitsa et al. 2010, Zubarevich 2012, Antipova and Titov 2016, Zamyatina and Pilyasov 2016, Gurova 2017, Dushkova and Krasovskaya 2018, Mingaleva et al. 2018).

Comparative studies and integrated assessments of migration processes in the regions of Eastern Siberia and the Far East were performed by many Russian scientists, including Mkrtchyan (2009), Vakulenko et al. (2011), Zayonchovskaya (2012), and Motrich (2016). Some authors described the influence of investments on regional development in their works. A study on the influence of the near-border location on the investment processes in Russia's regions using the methods of multivariance cluster analysis is presented in the work of Glazyrina et al. (2012); the influence of large investment projects on the social and economic development of Baikal region is described in the works of Dets (2014), and Sysoeva (2018). An analysis of the attraction and spatial distribution of direct foreign investments is given in the works of Dementyev (2017), and Minakir and Suslov (2018).

The aim of this article is to analyze the migration and investment activity in the regions and mono-specialized cities of the Siberian Federal District within the context of the Priority Social and Economic Development Areas creation and functioning.

\section{Methodology}

The methods of study include the analysis of statistical data, data processing and their geographical visualization. The statistical information from the databases of the Federal State Statistics Service was used to study the migration mobility issues. The analysis of the official statistics, investment projects summaries and data from the regional media concerning the implementation of projects were used for the study of the investment activity.

The rating of the investment attractiveness of SFD regions was analyzed based on the data of Expert-RA rating agency. Traditionally, it is based upon the official data from the Federal State Statistics Service and federal agencies. This rating estimates two parameters: the investment potential and the investment risk. The investment potential is composed of the presence of natural resources, labor force, fixed assets, infrastructure, and other factors influencing the potential investment volumes in the region. The investment risk includes the economic, social, financial, managerial, ecological and criminal risks.

\section{Selection of the Study Area}

This research is focused upon the administrative territories of the Russian Federation - regions of the Siberian Federal District (SFD) and their specialized single-industries, in which the Priority Social and Economic Development Areas were created: Irkutsk Region (Sayansk, Cheremkhovo, Usolye-Sibirskoye), Trans-Baikal Territory (Krasnokamensk), the Republic of Buryatia $^{1}$ (Selenginsk), the Altai Territory (Novoaltaysk, Zarinsk), Novosibirsk Region (Linyovo), the Republic of Khakassia (Abaza), Krasnoyarsk Territory, Kemerovo Region (Novokuznetsk, Anzhero-Sudzhensk, Yurga), Omsk and Tomsk Region (Fig. 1).

1) Until $3^{\text {rd }}$ of November, 2018, the Trans-Baikal Territory and the Republic of Buryatia were parts of the Siberian Federal District; later, they were included in the Far Eastern Federal District by the Decree of the President of the Russian Federation. 


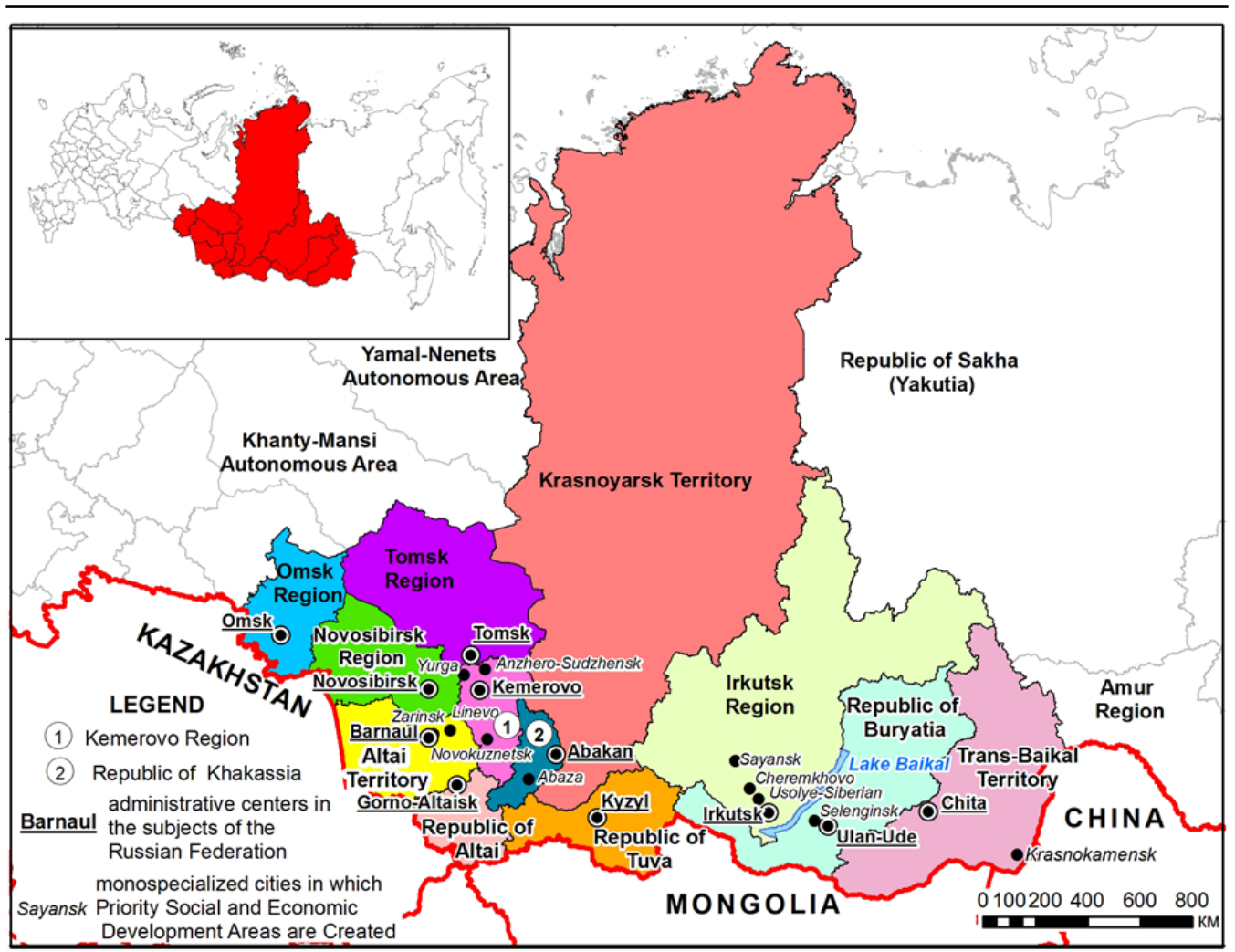

Fig. 1 - Regions and Specialized Monosettlements with

Priority Social and Economic Development Areas in the Siberian Federal District Source: Drafted by the authors

\section{Results}

Migration Activity in the Regions of the Siberian Federal District

Migration activity in the regions of the Siberian Federal District allows to describe the current tendencies and peculiarities of population redistribution at the present stage. Taking into account the absence of sufficient information concerning migration in specialized monosettlements, the general description of the regions allows to speak about the development of urban areas in general.

The available statistical data allow to perform an analysis by regions without regard to the migratory exchange with foreign countries - only interregional migration. In 2016, Omsk Region takes the leading position in migratory out flow (-10192 people). Considerable losses are also present in Kemerovo Region (-9391), the Altai Territory (-7952) and Trans-Baikal Territory (-6821). Population growth is present in Novosibirsk Region (2618 people) which possess considerable potential for scientific and technological development, and for the Republic of Khakassia (71 people) (Russian Federal State Statistic Service 2016).

The presence of a social and economic crisis is also confirmed by the net migration parameters 
per 10000 people. The most unfavorable situation is observed in the near-border Trans-Baikal Territory - in 2016, this coefficient amounted to -60. It is followed by the Republic of Tyva (-42), the Republic of Buryatia (-33), Irkutsk and Tomsk regions (-30). Positive dynamics is observed in Novosibirsk Region, Krasnoyarsk Territory, the Republic of Khakassia, and the Altai Territory (Regions of Russia 2018).

We should mention the importance of such parameter as the quantity of people born and living in the place of birth or beyond its borders. This parameter allows to characterize transregional and intraregional migration. Unfortunately, such statistical information is collected only during census years; therefore, the most recent data used in the study are the data from the 2010 census. According to Bulaev (1998), this parameter can be used to determine the stability of population cores in the regions. Based on the above, we can characterize the demographic development and migratory movements of the population in these territories. In SFD, the population core is formed by the locally born people, with the exception of the Republic of Khakassia (Shvorina and Faleychik 2018). In this Republic, the relative share of people born in the region and still living here exceeds $50 \%$, which points to a considerable influence of the migratory movements of the population (Fig. 2).

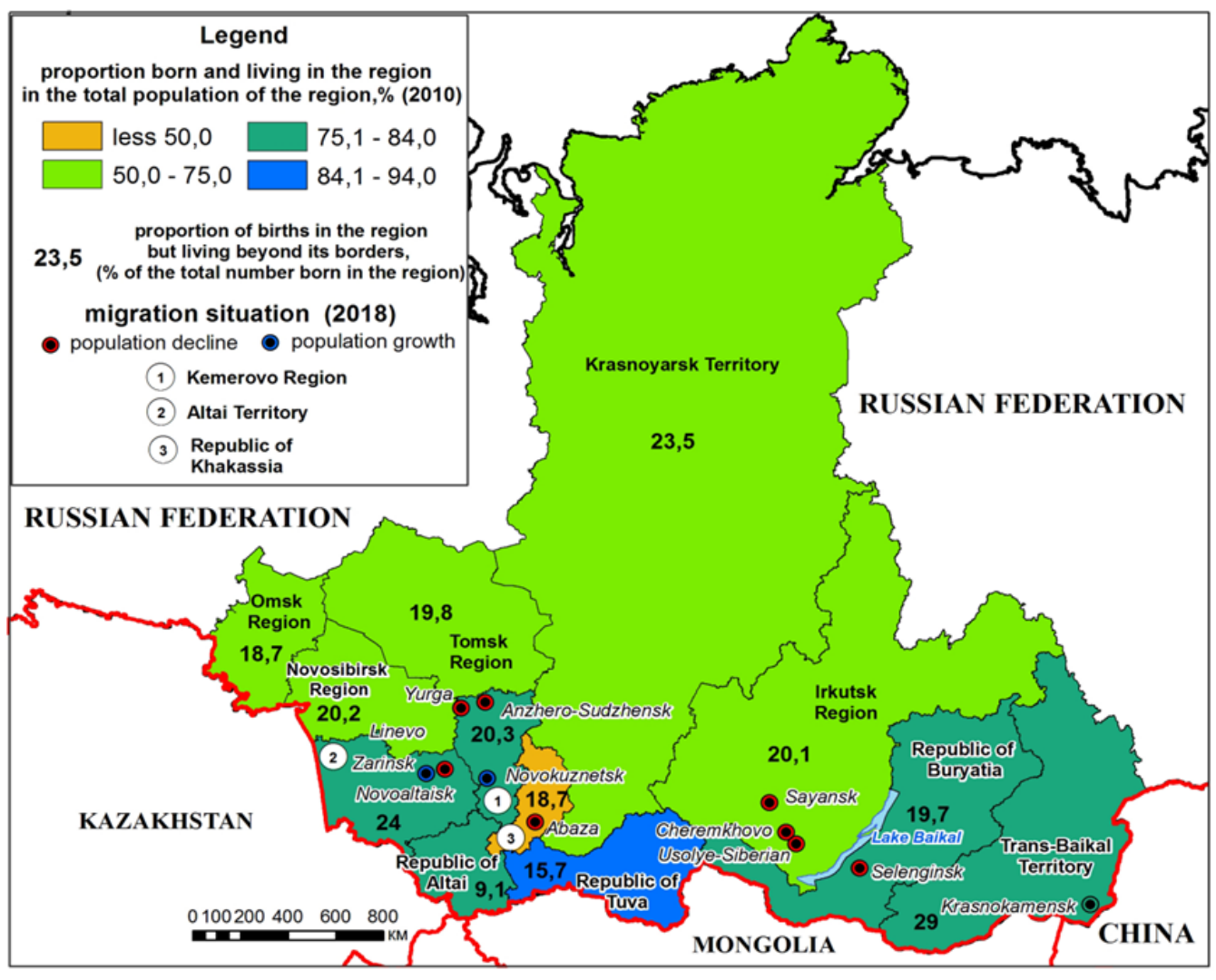

Fig. 2 - Percentage of people born and living in the regions of the Siberian Federal District submitted to the 2010 All-Russian Census

Source: calculated by the authors using the data provided by Rosstat 
In order to characterize the internal mobility of the population, we have analyzed the data concerning the people born in SFD regions, but living in other regions of the Russian Federation. Among all SFD regions, the least migratory mobility is observed in the Republic of Altai - nearly $9 \%$ of its population have changed the place of residence. The largest dispersion throughout the territory of the country is characteristic of the Trans-Baikal Territory population nearly one-third of 2010 census respondents. At large, non-alien population is preserved in SFD regions.

As for the specialized monosettlements in SFD regions, the migrational situation reflects an increasing degradation of urban areas. In 2018, virtually, all mono-specialized cities (except Novokuznetsk and Novoaltaysk), from the list of Priority Social and Economic Development Areas, show a rapid and uncompensated population loss. Formed by PSEDA in these specialized monosettlements and the declared volume of investments has not yet reflected in any way in the migration indicators. This may be explained by the inertia of the development mechanisms of PSEDA themselves, the problems of the bureaucratic nature and the difficulty of finding investors in the domestic market of the country. The qualitative and quantitative structure of the population is substantially worsening. The migratory portrait of the population of single-industry settlements includes residents of young ages and a more able-bodied population. By gender, among the inhabitants of the 12 considered settlements, in 8 of them there are more migrant women than men. Young people in search of better places for studying and work are striving for large cities - Moscow, St. Petersburg, Novosibirsk, Krasnoyarsk, hoping to stay there for permanent residence. The geography of similar routes is typical for able-bodied residents, while for many of them, unlike young people, there are difficulties in securing a family at a new place of residence. Socio-economic conditions are the main pushing migratory factors for the population - job search and decent wages are always the main requirements of the migrants. All this affects the qualitative and quantitative composition of the population of monofunctional settlements. The countryside, at the present stage, is not able to make up for the missing shortage of youth and the working population. Mono-specialized cities become hostages of a difficult socio-economic situation, which without the help of the state is quite difficult to solve.

\section{Investment Activity in SFD Regions}

The investment attractiveness of the regions serves as an important parameter of social and economic development of territories. Investment generally determines the well-being of the population and it is one of the factors decreasing the outward migration flow. The dynamics of these parameters reflect the possibilities of improvement of the basic premises for market development in these regions.

From 2010 to 2017, the Central Federal District (CFD) and the Ural Federal District (UFD) take the leading positions by the volume of investments in capital assets among the RF federal districts (Table 1). The volume of investment resources (in absolute measures), by federal districts, has increased by the year 2017 in comparison with 2010 and their share in the total volume of the Russian Federation has decreased in all districts, except for CFD and UFD. This points to the escalating differentiation of the regions and the territorial unevenness of the investment activity.

In terms of per capita investments in 2017, the Siberian Federal District is at the seventh place, while the Far Eastern one is at a second place, which, on the one hand, is explained by the larger population in the Siberian regions compared to the Far East and, on the other hand, it is caused by the implementation of major investment projects in the East of the country (Fig. 3). 
Migration and Investment Activity in the Regions of the Siberian Federal District of the Russian Federation

Table 1

Investments in Capital Assets by the Federal Districts of the Russian Federation (USD)*

\begin{tabular}{|c|c|c|c|c|c|}
\hline \multirow[t]{2}{*}{ Federal District } & \multirow[t]{2}{*}{$\begin{array}{l}\text { Total Volume } \\
\text { in } 2010-2017^{* *}\end{array}$} & \multirow[t]{2}{*}{$2010^{\star * *}$} & \multirow[t]{2}{*}{$2017^{\star \star \star *}$} & \multicolumn{2}{|c|}{$\begin{array}{c}\text { Share of Federal Dis- } \\
\text { trict in the Total Vol- } \\
\text { ume by RF (\%) }\end{array}$} \\
\hline & & & & 2010 & 2017 \\
\hline Russian Federation & 2453491.6 & 301353.1 & 273638.4 & 100 & 100 \\
\hline Central & 608300.6 & 69141.3 & 71516.0 & 22.95 & 26.13 \\
\hline Northwestern & 276978.0 & 37352.8 & 32081.8 & 12.39 & 11.72 \\
\hline Southern & 233737.4 & 29896.7 & 23947.2 & 9.92 & 8.75 \\
\hline North Caucasian & 81274.9 & 10319.8 & 8634.9 & 3.42 & 3.15 \\
\hline Privolzhsky & 349851.0 & 47331.9 & 41340.3 & 15.7 & 15.10 \\
\hline Ural & 417406.3 & 49089.5 & 49187.1 & 16.28 & 17.97 \\
\hline Siberian & 256082.0 & 32284.2 & 26067.8 & 10.71 & 9.52 \\
\hline Far Eastern & 177928.5 & 25936.7 & 20862.9 & 8.60 & 7.62 \\
\hline
\end{tabular}

*Source: Federal State Statistics Service (2018), calculated by the authors

${ }^{* *}$ Average rate for the period of 2010-2017: 42.69 rubles for 1 US dollar

***The average annual rate in 2010: 30.37 rubles per 1 US dollar

${ }^{* * * *}$ Average annual rate in 2017: 58.35 rubles for 1 US dollar

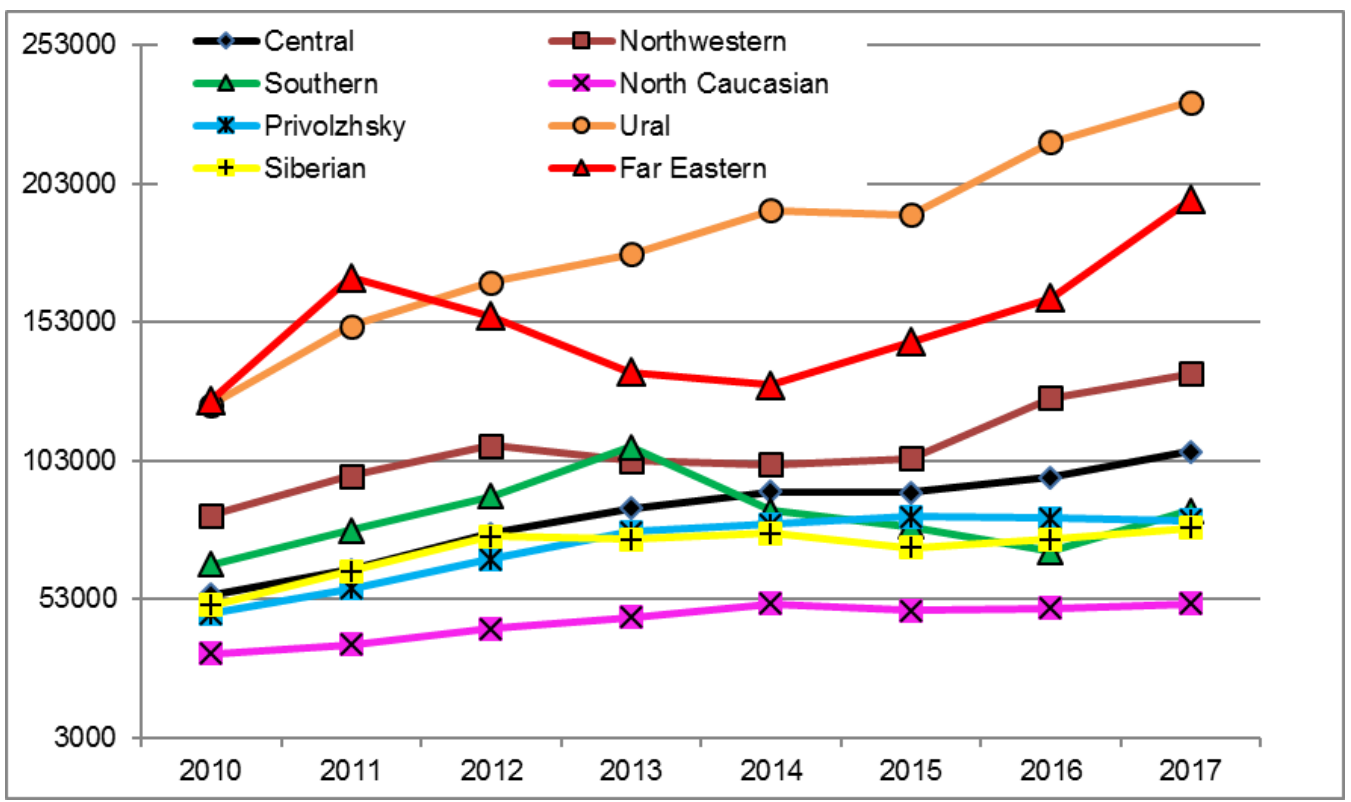

Fig. 3 - Dynamics of Investments in Capital Assets per Capita (in Current Prices, Rubles), by Federal Districts

Source: Rosstat

SFD regions in terms of investment dynamics into per capita capital assets do not show a significant growth in comparison with the Far Eastern Federal District, in which, after a stable 
decrease of this parameter during the 2012-2014-time period, a significant growth is being observed: from 2015 to 2017, increased investments in capital assets are reported. Nevertheless, the total volume of investments in the economy of the Siberian Federal District exceeds this parameter in the Far Eastern Federal District by $30.6 \%$. The negative dynamics of investment activity in the Far Eastern Federal District, observed from 2012 to 2015, is associated with the completion of major investment projects. The current growth of the investment activity in the Far East is, to some extent, associated with the creation of PSEDA in the Primorskiy Territory, the Khabarovsk Territory, the Amur Region, the Kamchatka Region, the Republic of Sakha (Yakutia), and Chukotka Autonomous Region. In 2015, nine such areas were created with 21 resident companies and the total amount of investments of 187 billion rubles, in 2016 - 14 PSEDA and 11 resident companies with the amount of investments of 450 billion rubles, and in 2017 - 18 PSEDA, 204 resident companies and 2175 billion rubles of investments.

As for the investments into the per capita capital assets, some significant intraregional differences are observed. According to the data, since 2015, decreased investments into the per capita capital assets have been virtually observed in all SFD regions, except Krasnoyarsk Territory, Trans-Baikal Territory, and Irkutsk Region (Fig. 4). The crisis events in the economy of Russia associated with the global oil price slumping and the imposition of sanctions have

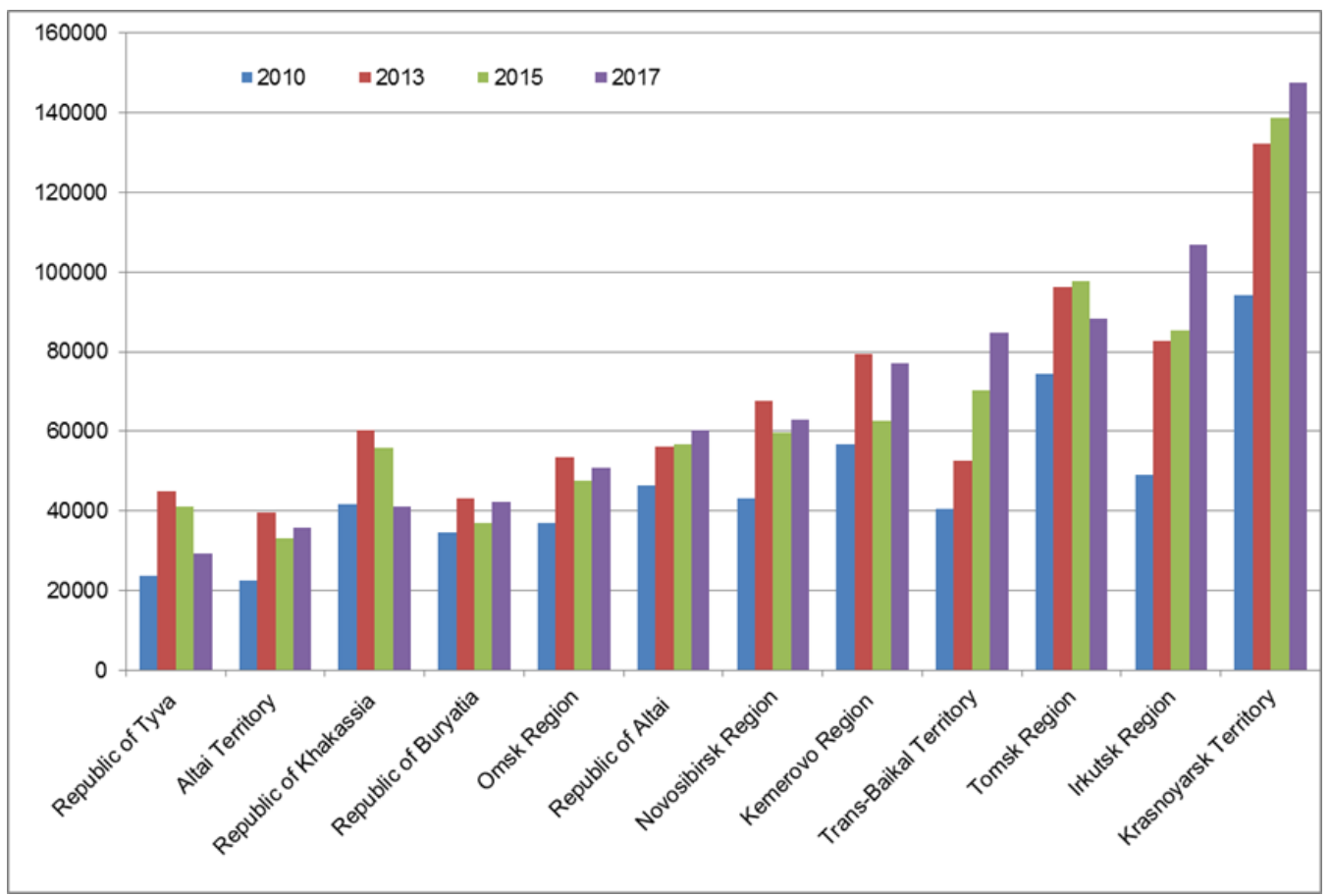

Fig. 4 - Investments into Capital Assets per Capita by SFD Entities (in Current Prices, Rubles)

Source: Rosstat

contributed to the problem. Among all SFD regions, the Krasnoyarsk Territory stands out in terms of social and economic development; also, it takes a leading position in the share of 
investments into capital assets in comparison with the total volume of investments in the district $-28 \%$ in 2017 (in absolute measures -424.7 billion rubles). This region consistently has been taking the leading position by the attraction of investments since 2010. Irkutsk Region is at second place (16.9\%, in absolute measures - 256.8 billion rubles). Over the period from 2010 to 2017, the Krasnoyarsk Territory has also been taking the leading position in the Siberian Federal District in the volume of investments per capita ( $1^{\text {st }}$ place), Tomsk Region had been at $2^{\text {nd }}$ place till 2015 and was replaced by Irkutsk Region in 2016; Kemerovo Region had been at $3^{\text {rd }}$ place till 2015, and was replaced by the Trans-Baikal Territory in 2015. The Altai Territory had been last till 2017, and it was replaced by the Republic of Tyva in 2017.

In the Republic of Tyva, the Republic of Khakassia and Tomsk Region, the decline continued till 2017. The share of the Trans-Baikal Territory was 6\% of the total SFD volume, in 2017. Recently, in the Trans-Baikal Territory, the investment activity has grown mostly at the expense of implementation of key investment projects of the region - "Russian Railways" JSC investment program implementation regarding the development and modernization of the Trans-Baikal Railway infrastructure, development of mineral deposits, machinery renewal of some production enterprises, implementation of agricultural investment projects, aimed at commercialization of 112.4 thousand hectares of farmland by 2020 .

Among the regions in which PSEDA functioning is planned, a more favorable situation with the attraction of investments is observed in Krasnoyarsk Territory, as well as in Tomsk, Irkutsk and Kemerovo Regions, which are also the key regions of the district.

In the structure of investments into capital assets by sources of financing over the period from 2010 to 2017, the total share of internal funds in SFD has increased from $52.1 \%$ to $55.4 \%$. In the majority of district regions (the Republic of Khakassia, the Altai Territory, Irkutsk, Novosibirsk, Kemerovo, Omsk and Tomsk Regions), the investment from internal funds

Distribution of Investments in Capital Assets by

Table 2 Sources of Financing (excluding Small Business Enterprises, \%)

\begin{tabular}{|c|c|c|c|c|c|c|}
\hline \multirow{3}{*}{ Territory } & \multicolumn{3}{|c|}{2010 r. } & \multicolumn{3}{|c|}{2017 r. } \\
\hline & \multirow[t]{2}{*}{$\begin{array}{c}\text { Internal } \\
\text { Funds }\end{array}$} & \multirow[t]{2}{*}{$\begin{array}{c}\text { Involved } \\
\text { funds }\end{array}$} & \multirow{2}{*}{$\begin{array}{l}\text { of which } \\
\text { Federal } \\
\text { Money }\end{array}$} & \multirow[t]{2}{*}{$\begin{array}{c}\text { Internal } \\
\text { Funds }\end{array}$} & \multirow[t]{2}{*}{$\begin{array}{l}\text { Involved } \\
\text { funds }\end{array}$} & \multirow{2}{*}{$\begin{array}{c}\text { of } \\
\text { which }\end{array}$} \\
\hline & & & & & & \\
\hline SFD & 52.1 & 47.9 & 10.1 & 55.4 & 44.6 & 7.1 \\
\hline Republic of Altai & 7.9 & 92.1 & 48.2 & 26.8 & 73.2 & 18.7 \\
\hline Republic of Buryatia & 31.6 & 68.4 & 14.2 & 48.8 & 51.2 & 24.1 \\
\hline Republic of Tyva & 12.6 & 87.4 & 30.9 & 38.0 & 62.0 & 32.0 \\
\hline Republic of Khakassia & 24.6 & 75.4 & 3.3 & 67.9 & 32.1 & 8.3 \\
\hline AltaiTerritory & 42.3 & 57.7 & 11.6 & 50.3 & 49.7 & 5.8 \\
\hline Trans-Baikal Territory & 21.1 & 78.9 & 30.4 & 27.3 & 72.7 & 4.7 \\
\hline Krasnoyarsk Territory & 58.4 & 41.6 & 11.3 & 46.7 & 53.3 & 9.0 \\
\hline Irkutsk Region & 58.5 & 41.5 & 5.4 & 65.4 & 34.6 & 6.0 \\
\hline Kemerovo Region & 64.8 & 35.2 & 3.0 & 68.2 & 31.8 & 3.0 \\
\hline Novosibirsk Region & 52.0 & 48.0 & 12.5 & 52.6 & 47.4 & 8.5 \\
\hline Omsk Region & 51.2 & 48.8 & 7.3 & 76.1 & 23.9 & 3.7 \\
\hline Tomsk Region & 46.1 & 53.9 & 5.4 & 70.8 & 29.2 & 2.8 \\
\hline
\end{tabular}

Source: Federal State Statistics Service (2018) 
dominates over the borrowed funds and it amounts from $50.3 \%$ to $76.1 \%$. In this regard, the Trans-Baikal Territory falls behind other entities of the Siberian Federal District with the lowest amount of internal funds since 2010 (27.3\% in 2017). The share of federal money in the majority of district regions tends to be reduced (Table 2).

In the structure of investments into capital assets by economic activity in the regions, in 2017 , mining, manufacturing, transportation and storage were the most attractive for business. Kemerovo Region (54\% of all financial investments in the region in the mining sphere) and Omsk region (nearly $55 \%$ of the total investment volume of the region fell into manufacturing) are the leaders by the percentage of investments by economic sectors (Regions of Russia 2018).

Analyzing this parameter in the district as a whole, we can distinguish the territories which are the definite leaders of economic development characterized by a high investment attractiveness. Krasnoyarsk Territory has the largest share of investments in the district, virtually, in all economic sectors. It is followed by Novosibirsk Region, Irkutsk Region and the Trans-Baikal Territory. Investments into mining is characterized by the largest percentage: $36.5 \%$ of the total investment volume of the district in the Krasnoyarsk Territory (128.5 billion rubles in absolute measures), $22.9 \%$ — in the Kemerovo Region (80.5 billion rubles in absolute measures), and $22.0 \%$ - in the Irkutsk Region (77.5 billion rubles in absolute measures). The manufacturing percentage holds the second place in these regions: $38.9 \%$ in the Krasnoyarsk Territory (81.0 billion rubles), and $15.0 \%$ - in the Irkutsk Region (31.2 billion rubles). Investments in manufacturing, agriculture, forestry and hunting dominate in the Altai Territory and the Novosibirsk Region (Regions of Russia 2018).

According to the national rating agency, evaluating the investment attractiveness of Russian regions, the investment ratings of SFD entities are referred to the following categories:

1. with reduced potential and moderate risk (Altai Territory, Omsk Region, Republic of Buryatia and Tomsk Region);

2. with average potential and moderate risk (Kemerovo Region, Irkutsk Region, Novosibirsk Region and Krasnoyarsk Territory);

3. with low potential and extremely high risk (Republic of Tyva);

4. with insignificant potential and high risk (Republic of Altai);

5. with insignificant potential and moderate risk (Republic of Khakassia);

6 . with reduced investment potential and high investment risk (Trans-Baikal Territory)

The Krasnoyarsk Territory is the largest region in SFD. By the volume of investments into capital assets per capita, the territory had been at the $14^{\text {th }}$ place among the regions of Russia at the end of 2017 (Regions of Russia 2018). The Implementation of the investment project for Vankor oil and gas field development allowed to attract investments into the economy of the region. The territory is characterized by moderate investment risks, the main of which are legislative, political, financial, social, ecological, and criminal. Additional regional investments risks of the territory are the underdevelopment of infrastructure, severe climatic and natural conditions, deficiency of labor force. All these factors aggravate the problem of increasing the investment attractiveness (Cheremnykh 2015).

The Irkutsk Region is an industrial region with dominant mining and primary processing of natural resources: oil production and refining, aluminum, wood processing and chemical industry. The implementation of major investment projects in the oil production, from 2010 to 2013, has provided an inflow of investments in the region. The introduction of a zero rate mineral tax and a zero rate crude oil export fee has contributed to this inflow. Since 2013, the share of investment into mining has decreased (Violin 2016). A moderate investment risk is characteristic of the region. It has such regional peculiarities as problems with the transport 
infrastructure availability and staffing issues.

The primary industry of the Tomsk Region, besides other priority areas (information technologies, science and education, agriculture and timber processing), is the oil and gas sector. The share of oil and gas sector in the industrial output of the region is of approximately $50 \%$ (Sharf and Grinkevich 2016). Tomsk Region is an innovation-developed resource region of the Siberian Federal District. It is emphasized (Sevastyanova 2016) that the development of the innovation sector has improved the image of the region and it has increased the possibilities for investment and the availability of highly-qualified specialists. The moderate investment risk of the region is associated with social and ecological risks.

Kemerovo Region is a region with evident resource specialization where investment flows into the mining sector, therefore the investment risk is closely related to the economy of the region. The contribution of mining to gross added value of the region, in 2016 , amounted to $29.7 \%$ (Regions of Russia 2018). The economic crises in the coal industry increased the investment risk of the region and it resulted in decreased investments and gross regional product.

The Omsk Region is a developed industrial and agricultural region with an advanced production and transport infrastructure (Mikhalyov 2018). The regional peculiarity of investment risks in the Omsk Region is associated with the deficiency of the labor force because of the high outward migration flow of the employable population.

The competitive advantage of the Novosibirsk Region is in its diversified economic potential including a developed industry, transport, communication, construction, agriculture, and commerce. The prospects of the region are associated with the development of scienceintensive innovative manufacturing methods, which increase the investment attractiveness of the territory. Above that, it is mentioned (Zemtsov and Smelov 2018) that the region has favorable institutional conditions for investors and business owners. The main investment risks in the region are social, managerial and ecological.

The Altai Territory is one of the main agricultural regions of Russia. The contribution of agriculture, hunting and forestry into the gross added value of the region amounted to $20.1 \%$ in 2016 (Regions of Russia 2018). Such competitive advantages of the region as favorable natural and climatic conditions, advantageous geo-economic position, diversified economy, and advanced technologies (Uskova and Razgulina 2015, Gerauf and Zelenina, 2017) create a favorable environment for the attraction of investments. The resource potential of the Altai Territory agro-industrial complex, the availability of land areas, the high demand for environmentally-friendly and natural products increase the investment attractiveness. The main investment risks of the territory characterized as moderate are the social, managerial and economic ones.

The Republics of Tyva, Khakassia, Buryatia and Trans-Baikal Territory are the depressed regions characterized by a decline in the main economic sectors, a low diversification of economy, an outward migration flow, the growth of unemployment, and decreased income levels. The republics of Altai, Tyva, and Khakassia are characterized by the lowest parameters of investment activity among the other entities of SFD. From 2009 to 2017, the Trans-Baikal Territory, according to the rating of investment attractiveness, had been referred to as a region with a decreased investment potential and high investment risk.

Thus, the majority of SFD regions is characterized by a moderate investment risk, while a medium investment potential is present only in the regions with developed industry (Novosibirsk Region, Irkutsk Region, Kemerovo Region and Krasnoyarsk Territory). The regions located in an unfavorable natural environment (Republic of Tyva, Trans-Baikal 
Territory) or with predominantly agricultural specialization - Altai regions and Republic of Buryatia - lag behind in the investment activity. In comparison with the migration indicators, the correlation with the investment migration growth is observed only for the Novosibirsk region.

\section{Discussion}

The migratory mobility of the population is caused by the unevenness of the social and economic development in the regions of the country. The regions of the country are differentiated by the population's quality of life; therefore, the parameters of migratory movements can serve as indicators of life quality in specific territories. The creation of Priority Social and Economic Development Areas can serve as a mechanism for quality of life improvement in the regions and, correspondingly, for decreasing the outward migration flow. These measures are mostly aimed at improving the social and economic development of mono -specialized cities and the diversification of their economy, while relieving the tension of regional labor markets. The investment activity of the residents of the studied territories, also, in many respects, serves as an indicator of the level of social and economic development of these territories and their perspectives. The creation of PSEDA causes a multiplicative effect - the creation of new work places and the reconstruction of the already existing ones in the different sectors of the economy. Generally, this contributes to the welfare of the population and to a positive migration balance.

The Ministry of Economic Development of the Russian Federation differentiated all specialized monosettlements in the country by the level of social and economic development. Within this context, among the SFD regions, only the cities of Novokuznetsk and Novoaltaysk (2018) have the most favorable situation among the regions of the Siberian Federal District (Fig. 5). Only in their case, cities are currently experiencing migration growth. In relation to the remaining monosettlements, negative development trends are traced. For mono-settlements (Zarinsk, Sayansk and Cheremkhovo), there are risks of worsening the socio-economic conditions. Most monosettlements (Yurga, Abaza, Usolye-Sibirskoye, Selenginsk, Anzhero-Sudzhensk and Krasnokamensk) belong to settlements with a difficult socio-economic situation. The significant complexity of the situation in the cities of Yurga and Krasnokamensk is indicated by the highest migration outflow of the population among all considered settlements. Migration indicators in this regard correlate with the standard of living of the population in these settlements, confirming the well-known thesis that "the population votes with its feet".

In spite of the types of mono-specialized cities distinguished by the level of social and economic development, the volumes of planned investments in PSEDA also reflect their specific investment attractiveness. Mostly, this can be correlated to the existing specialization of the settlements and the activity of the residents. The investments in the monosettlements of the Siberian Federal District will be directed mainly to industrial production and wood processing. The largest volume of planned investments accounts for the city of Sayansk (49.8 billion rubles), where the construction of two plants for the production of methanol and naturalgas liquefaction, the creation of an added-value wood conversion center and works for PVC processing and the manufacturing of furniture are planned (Ministry of Economic Development of Russia 2018). Considerable investments into the economy of Usolye-Sibirskoye (18 billion rubles) and Anzhero-Sudzhensk (16 billion rubles) are planned. As for Usolye-Sibirskoye, these investments are planned for the creation of infrastructure for the "Cluster HIMPROM Usolye" (Usolye Chemical Production Cluster) industrial park. As for Anzhero-Sudzhensk, the investments are planned for the development of agriculture, the production of rubber and plastic items, construction materials, and pharmaceuticals (Bezformata 2016). The investments of the residents of other specialized monosettlements are substantially lower. 


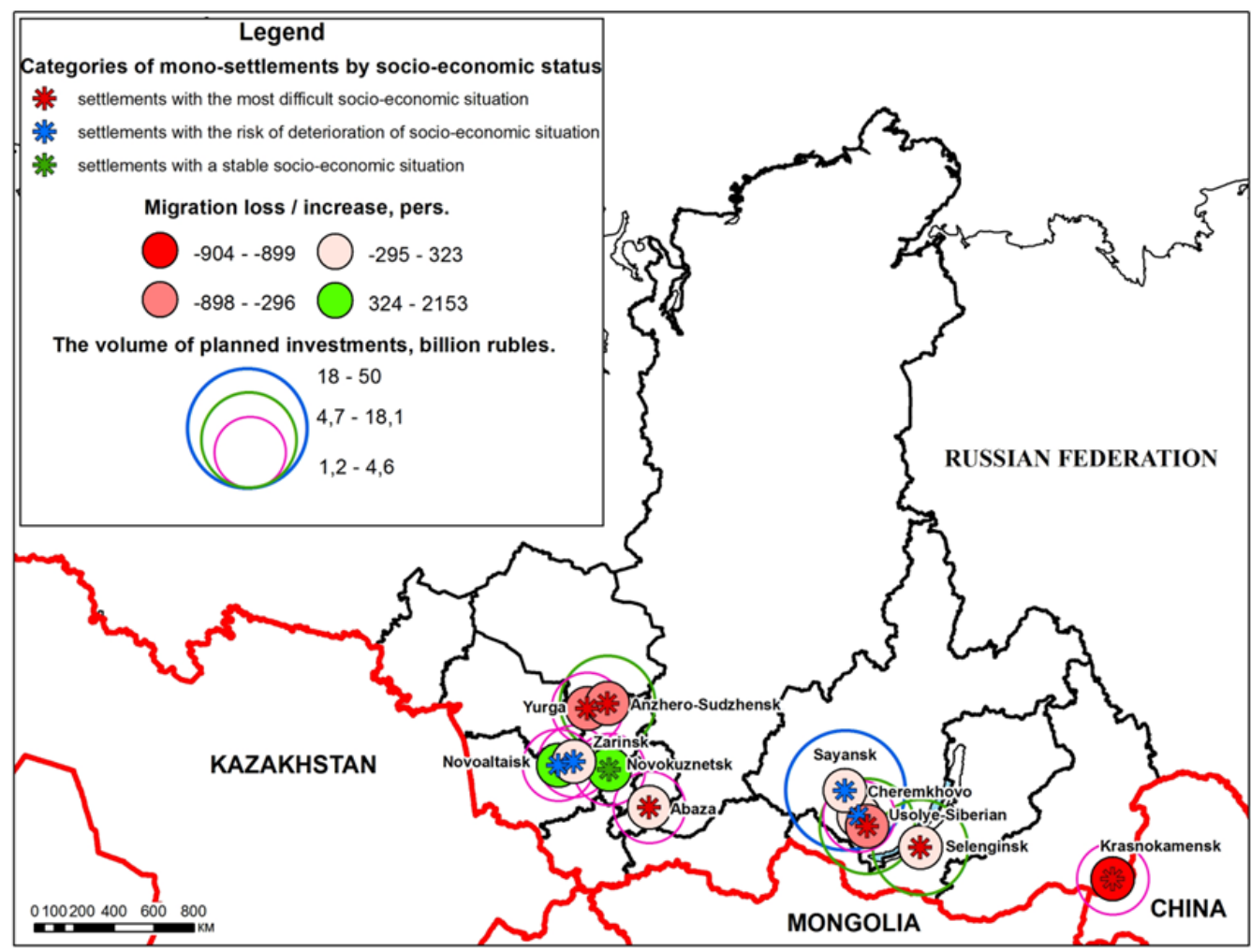

Fig. 5- Level of Social and Economic Development, Migration and Investment Activity in SFD PSEDA (2018)

Source: calculated by the authors using the data provided by Rosstat

Taking into account the fact that the studied PSEDS in SFD, mainly, have just been created, and currently only several residents commenced the first stage of implementation for the investment projects, PSEDA has not yet had a noticeable effect on reducing the monodependence of the economy of settlements and the improvement of the quality of life. Above that, some problems with the organization and functioning of PSEDA also exist. In our opinion, it is possible that the specialized monosettlements will not be able to attract investors and to solve the problems of infrastructure availability, the deficiency of highly-qualified specialists, etc. Such problems significantly complicate the development of PSEDA in mono-specialized cities.

\section{Conclusions}

The current stage of economic development of the country determines the creation of new mechanisms for regional development and the management of territories. Thereby, new methods of "secondary social and economic development" of the territories and their regional management driven by the market economy do not mean the complex Soviet-type development of territories and the large-scale labor migration. Under modern conditions, the mechanism of targeted development (Priority Social and Economic Development Area PSEDA) is actively used. Their functioning in SFD mono-specialized cities is based on resident 
companies - locomotives of economic development which can decrease the monospecialization of settlements. However, the monoprofile type of economic development specific to these settlements and their current social and economic situation causes difficulties in the attraction of investors in spite of the particular state of policy favors.

The aspects of the migratory activity of the population within the regions and mono-specialized cities of SFD discussed in this article prove the presence of considerable migratory movements of population (mostly of employable age), which intensifies demographic risks. When studying migration flows and investment attractiveness in the subjects of the Siberian Federal District and their single-industry towns, the authors came to the conclusion that the relationship between these two processes, important for the socio-economic development, can be traced in the most industrially and innovative developed regions. The presence of a correlation between them is characteristic of only one such region (Novosibirsk region). For this period of time, in the context of the implementation of the law on the creation of PSEDA territories, the investments of the residents did not have a significant effect on the migration indicators in single-industry towns.

The greatest success in the development of PSEDA in the SFD based on regional analysis is possible in the Krasnoyarsk Territory, Irkutsk, Novosibirsk, Tomsk and Kemerovo Regions. An effective state and regional policy aimed at the maximum reduction of investment risks is necessary. To some extent, this is provided by such policy favors for PSEDA resident companies as tax exemptions and the priority development of the infrastructure at the expense of federal money.

\section{Acknowledgements}

The paper was prepared within the framework of Project XI.174.1.8 according to the Siberian Branch of the Russian Academy of Sciences Programme of Basic Scientific Research for 2017 2020. We would like to thank the reviewers and the editors of JURA for their helpful suggestions for improving our paper.

\section{References}

AGRAWAL A., COCKBURN I., ROSELL C. (2010), Not Invented Here? Innovation in company towns, Journal of Urban Economics 67 (1), 78-89.

ANAS A., XIONG K. (2005), The formation and growth of specialized cities: efficiency without developers or Malthusian traps, Regional Science and Urban Economics 35 (4), 445470.

ANIMITSA E. G., BOCHKO V. S., PESHINA E. V., ANIMITSA P. E. (2010), Conceptual approaches to developing a strategy for the development of a single-industry cities, Izd-vo UrGEU, Ekaterinburg.

ANTIPOVA E. A., TITOV A. N. (2016), The Single-Industry Towns of Belarus: Differences in Demographic and Economic Development, Journal of Settlements and Spatial Planning 7 (2), 125-136.

BAŃSKI J., CZAPIEWSKI K., GÓRCZYŃSKA M. (2016), Impact of the locations of small towns in Mazovia (Poland) on their socio-economic structure and on their role in relation to the neighboring rural areas, Journal of Urban and Regional Analysis 8 (2), 117-131.

BARTIK T. J. (2009), The Revitalization of Older Industrial Cities: A Review Essay of Retooling for Growth, Growth and Change 40 (1), 1-29.

BERUBE A., MURRAY C. (2018), Renewing America's economic promise through older industrial cities, Brookings, Retrieved from: www.brookings.edu.

BEZFORMATA (2016), Usolye-Sibirskiy - Priority Social and Economic Development Areas, Retrieved from: www.irkutsk.bezformata.com.

BULAEV V. M. (1998), Ethno-national characteristics of the formation of the population of Eastern Transbaikalia (socio-geographical interpretation), BNTS SB RAS, Ulan-Ude. 
BURCHARDI K. B., CHANEY T., HASSAN T. A. (2019), Migrants, Ancestors, and Foreign Investments, The Review of Economic Studies 86 (4), 1448-1486.

CHEREMNYKH E. A. (2015), The current state of investment in the Krasnoyarsk Territory, Modern problems of economic and social development 11, 115-117.

DEMENTYEV N. P. (2017), Foreign direct investment from abroad: estimates based on data from the Bank of Russia and Eurostat, Russian Economic Journal 2, 56-69.

DETS I. A. (2014), Impact of large investment projects on the socio-economic development of the Baikal region, Izvestia of Irkutsk State University 11, 14-29.

DUSHKOVA D., KRASOVSKAYA T. (2018), Post-Soviet single-industry cities in northern Russia: movement towards sustainable development. A case study of Kirovsk, Belgeo 4, 1-24.

GERAUF Y. V., ZELENINA E. A. (2017), The role of investment in the socio-economic development of the region, Agrarian science - agriculture Altai State Agrarian University, 157159.

GLAZYRINA I. P., FALEICHIK A. A., FALEICHIK L. M. (2012), Cross-border cooperation in the light of investment processes: more minuses than pluses so far, Problems of Economic Transition 55 (6), 43-62.

GUROVA O. (2017), The main tendencies of social and economic transformation of cities in the Trans-Baikal territory, Journal of Urban and Regional Analysis 9 (2), 173-186.

EVERITT J., GILL A. M. (1993), The social geography of small towns, in: Bourne L. S., Ley D. E. (eds.), The Changing Social Geography of Canadian Cities, McGill-Queen's University Press, Montreal and Kingston, pp. 252-264.

FENSORE I. (2017), The Impact of Migration on Foreign Direct Investments, Retrieved from: www.alexandria.unisg.ch.

HALSETH G., SULLIVAN L. (2003), 'The Bright Lights of the City': Intra-Regional Migration and the Challenge for Resource-Dependent Towns, Geography Research Forum 23, 138-168.

JAVORCIK B. S., ÖZDEN Ç., SPATAREANU M., NEAGU C. (2011), Migrant networks and foreign direct investment, Journal of Development Economics 94 (2), 231-241.

KUGLER M., LEVINTAL O., RAPOPORT H. (2017), Migration and cross-border financial flows, Policy Research Working Paper 8034, World Bank, Washington, DC.

MIKHALYOV O. V. (2018), Problems of Transformation of the Regional Economy (on the Example of the Omsk Region), Structural Transformations of the Territorial Economy: in Search of Social and Economic Balance, 145-150.

MKRTCHYAN N. V. (2009), Migration mobility in Russia: estimates and problems of analysis, Spero 11, 149-164.

MINAKIR P. A., SUSLOV D. V. (2018), Foreign direct investment in the economy of the Russian Far East, Economic and Social Changes: Facts, Trends, Forecast 11 (3), 41-56.

MINGALEVA Z., ZHULANOV E., SHAIDUROVA N., MOLENDA M., GAPONENKO A., ŠOLTÉSOVÁ M. (2018), The abandoned mines rehabilitation on the basis of speleotherapy: used for sustainable development of the territory (the case study of the single-industry town of mining industry), Acta Montanistica Slovaca 23 (3), 312-324.

MINISTRY OF ECONOMIC DEVELOPMENT OF RUSSIA (2018), On the creation of a territory of advanced socio-economic development Sayansk (Irkutsk Region), Retrieved from: www.government.ru.

MOTRICH E. L. (2016), Demographic situation in the Far East of Russia: main trends and challenges, Population 1 (71-1), 25-33.

REGIONS OF RUSSIA (2018), Socio-economic indicators, Rosstat, Moscow.

SEVASTYANOVA A. E. (2016), Creating the conditions for innovation development of resource-based regions, Region: Economics and Sociology 1 (89), 209-232.

SHARF I. V., GRINKEVICH L. S. (2016), Assessment of hard-to-recover oil reserves production potential in Tomsk region, R-Economy 2 (1), 123-131.

SHVORINA K. V., FALEYCHIK L. M. (2018), Main Directions of Migration Mobility in 
the Siberian and Far Eastern Federal Districts, Economy of Region 14 (2), 485-501.

SYSOEVA N. M. (2018), Forest investment in the Russian part of the economic corridor China-Mongolia-Russia, IOP Conference Series: Earth and Environmental Science 190, 012064.

USKOVA T. V., RAZGULINA E. M. (2015), On the role of investment in the socioeconomic development of territories, Economic and Social Changes: Facts, Trends, Forecast 2 (38), 72-89.

VAKULENKO E. S., MKRTCHYAN N. V., FURMANOV K. K. (2011), Econometric analysis of factors of internal migration in Russia, Montenegrin Journal of Economics 7 (2), 2133.

VIOLIN S. I. (2016), Improving the state policy of the Irkutsk region in the field of attracting investment, Problems of socio-economic development of Siberia 3 (25), 9-18.

ZAMYATINA N., PILYASOV A. (2016), Single-Industry Towns of Russia: Lock-In and Drivers of Innovative Search, Foresight and STI Governance 10 (3), 53-64.

ZAYONCHKOVSKAYA Z. A. (2012), Federal Districts on the Migration Map of Russia, Region: Economics and Sociology 3 (75), 3-18.

ZEMTSOV S. P., SMELOV Y. A. (2018), Factors of Regional Development in Russia: Geography, Human Capital, and Regional Policies, Journal of the New Economic Association 4 (40), 84-108.

ZUBAREVICH N. V. (2012), Cities as the Centers for the Modernization of the Economy and Human Capital, Sociological Research 51 (4), 3-27.

Initial submission: 10.04 .2019

Revised submission: 08.10.2019

Final acceptance: 06.01.2020

Correspondence: Institute of Natural Resources, Ecology and Cryology, Siberian Branch of the Russian Academy of Sciences, PO Box No. 1032, 16-a, Nedorezova Str., Chita, the Trans-Baikal Territory, 672002, Russia.

Email: lesg@bk.ru 